\title{
加藤陸奥雄 先生を偲んで
}

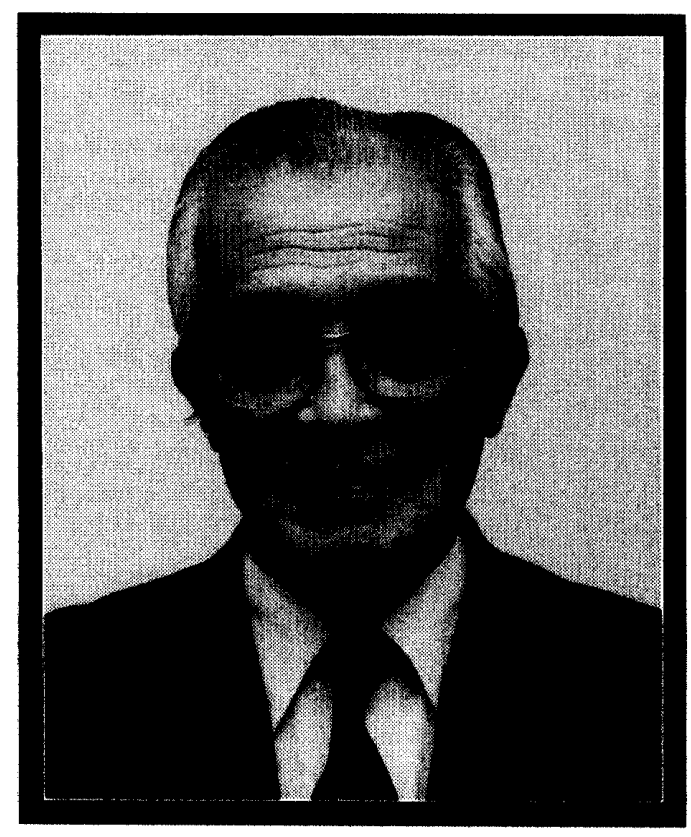

日本衛生動物学会名誉会員の加藤陸奥雄元東北大学学長は, 平成 9 年 3 月 8 日逝去されました. 享年 85 歳でした。

加藤先生は昭和 10 年に東北帝国大学理学部生物学学科を卒業されました. 当時は生態学の講座 は植物学だけでしたので, 動物分類学講座で独自の昆虫の生態学研究を始められました. その当時 は訪花昆虫の日周期性についての研究をテーマとされていましたが, きわめて小型の昆虫である七 メマルカッオブシムシの体温を計り，それと活動性についての関係を明らかにされた研究は極めて 先駆的でした. また，研究に統計的方法を取り入れたことであ当時としては珍しいことで，これら により，日本動物学会賞を授与されました。

昭和 19 年農商務省の農事試験場に移られ, 生態学者の八木誠政氏らと研究に従事し, 戦争激化 にともない秋田へ疎開，その期間に後に出版した“作物害虫概論”における害虫を対象とした二 ニークな生態学を確立されました。昭和 22 年に東北大学理学部生物学学科に教授として戻られ, 各種の動物群集の研究を手掛け, なかでも, ブナの木の樹洞に生息する生物群集の解析など注目を あびる研究を残されましたが, その中にブナノキャブカがおり, その後お墓のあかうけ, 竹筒, そ の他各種の水域の蚊の生態を研究され，またその頃から蚊や八エを無くす運動へ打ち込まれるよう になられました，弟子達にも蚊やハエを研究テーマとして与え, 加藤研究室は一時, 蚊の生態研究 のメッカとなりました.

東北大学学長をお辞めになると直ぐ新設の大学入学試験センター長に就任され, 仙台と東京を行 き来されておられました，その後も宮城県美術館館長をつとめられ，昨年末までいくつあの自然保 護関連の審議会等の仕事で忙しいとおっしゃっておられました。

先生のお書きになった “蚊の生態”という本は私が学生の頃に既に入手し難いものでしたが，出 来たら多くの人に読んで頂きたいと思っています，学生時代は蚊を扱わず，はからずもその後で蚊 の研究をした弟子の一人としてここに謹んで追悼の意を表します。

(安 野 正 之) 